National Technical University of Ukraine "Igor Sikorsky Kyiv Polytechnic Institute", Publishing and Printing Institute, Kyiv, Ukraine

\title{
The Roots of Confrontation: Energy Aspect of Hybrid Warfare
}

\section{Korzenie konfrontacji: energetyczny aspekt wojny hybrydowej}

\section{- Abstrakt •}

Artykuł dotyczy problemu użycia „broni energetycznej" w wojnie hybrydowej. Autor dokonuje retrospektywnego przeglądu wykorzystania „broni energetycznej” przez Rosję przeciwko Ukrainie. Pokazuje historyczne korzenie konfrontacji, począwszy od czasów rewolucyjnych (1917-1921).

Słowa kluczowe: wojna hybrydowa; "broń energetyczna”; wojny gazowe

\section{- Abstract -}

The article deals with the problem of usage of "energy weapon" in hybrid war. The author makes retrospective review of "energy weapon" usage by Russia against Ukraine. Author shows the historical roots of confrontation, starting from the revolutionary times (1917-1921).

Keywords: hybrid warfare; "energy weapon"; gas wars

The term "hybrid war" for the last several years has been constantly present in the information space of Ukraine and Europe. This term could be met only in special military-historical or military-political texts. But now it is without a doubt intended to explain the specificity of the confrontation between Russia and Ukraine.

Hybrid war is a set of state actions of the military, information, diplomatic, economic character aimed to solve the tasks of the submission one state's interests to another, which does not exclude the formal preservation of the sovereignty of the victim of aggression.

But a hybrid war is rather a set of tools that are used depending on the needs and abilities of the victim to resist, chosen again and again according to the 
aggressor's goals. Figuratively speaking, the hybrid war is always the choice of a unique combination of items from the aggressor's "menu", that contains sections "terrorism", "weapons of mass destruction", "ethnic clashes", "economic pressure", etc. (Gerasimov, 2013). We may say that energy is a special proposition.

However, the energy dimension of the hybrid war was ignored by experts in Ukraine (Mustonen, 2014). The significant exception is the papers of think tank Centre for Global Studies Strategy XXI and its head Mykhailo Honchar (Gonchar, Chubyk, Ishchuk, 2015). However, not all Western experts overlook the factor of the energy weapons use by Russia. Forbes columnist, an economist and a historian, analyst, who knows Russia well, author of several books, Paul Gregory wrote quite seriously about gas as a weapon in Putin's hands (Gregory, 2014).

Such position of Ukrainian specialists can be explained by the fact that this is not a new threat to Ukraine. Energy factor seemed to be lost against the backdrop of terrorists, propaganda and armed confrontation. Energy confrontation is no longer a new challenge, as memories of gas wars 2005-2006 and 2008-2009 are still fresh.

The problems of gas supply seem to be solved. Ukraine is not dependent on Russian gas for 3 years already. And now, when the challenge is answered, we may allow ourselves to look deeper in $20^{\text {th }}$ century and try to find the roots of such position of Russia.

So, in this article I will make a review of the energy relations between Ukraine and Russia. I will try to show which factors influenced the forming of the background of the modern energy relations between two countries and which are the historical roots of the conflict.

\section{Revolution Time: 1917-1921}

Conflict potential of energy relations between Ukraine and Russia goes back to the early twentieth century and is connected not with gas, but with coal. In 1917 coal mines in Donbass region produced about $87 \%$ of all coal production of the former Russian empire. And this fact affected the attitude of the Bolsheviks towards Ukrainian independence. Russia simply could not survive, and Bolshevik's could not win the civil war without coal supplies from Ukraine. No wonder that Ukraine was on Bolshevik's wish-list.

Thus, Grygoriy Pyatakov (the Bolshevik revolutionary leader during the Russian Revolution, and member of the Left Opposition) emphasized at the general meeting of the Kiev city organization of the Bolsheviks in early June 1917: "Russia cannot exist without the Ukrainian sugar industry, the same can be said about coal 
and bread" (Yefimenko, 2008). While the Central Council of Ukraine was busy with cultural and educational affairs and did not object against the exhausting of Ukraine, the Soviet government was patient (more or less). As soon as the Ukrainian governments' attempts to achieve economic independence became clear and obvious, the Manifesto to the Ukrainian Government with Ultimate Requirements for the Central Council of Ukraine was edited - on December 17 (4), 1917.

Sometime before, in autumn 1917, Donbas appeared in the center of armed struggle. On one hand, in the III Universal of the Central Council of Ukraine (November 7,20) Donbas was declared a part of Ukrainian National Republic. On the other hand, on the territory of the Province (Oblast) of the Don Cossack Host was established the regime of General Kaledin. Kaledin wanted to extend control over the whole territory of the Donbas, which turned out to conquering several local Soviet of Workers' Deputies. However, the Bolsheviks succeeded not only in stopping Kaledin's attack, but also they managed to establish full control in the Donetsk region (Yefimenko, 2008).

For Soviet authorities the undeniable goal was to modernize the heavy industry. Modernization meant the growth of the Bolsheviks' social base - the workers, the proletariat. And Donbass and its coal were the key resources for modernization and industrialization, as well as in strengthening the working class. And although during the revolution, when the economy was naturalized, the control of the agrarian sector gave to the Bolsheviks the key to victory (starving cities demanded bread first, not coal). But bread was not the only valuable thing in Ukraine for the Kremlin. Coal and metal were also extremely important resources for military restructuring of the economy. In the resolution of the Central Committee of the Russian Communist Party (Bolsheviks'), dated April 8, 1919, it was stated that "the most pressing task in Ukraine is the maximum use of fuel, metal, existing factories and workshops, as well as food supplies" (Yefimenko, 2008).

But the most compelling evidence of the Bolshevik's wish to establish control over the energy resources of Ukraine was the experience of setting up a DonetskKryvyi Rih Soviet Republic in 1918. It existed for about a month only (February 12-March 29), had a formal center in Kharkiv, but its' heart was in Donetsk coal and Krivyi Rih iron ore basins.

In November 1917, on the initiative of Fedir Sergiev (Artem), the regional executive committee of the Soviets adopted a decision to transform the DonetskKryvyi Rih basin into an independent administrative-territorial unit, which was supposed to be part of the Soviet Russian Federation in future.

The First All-Ukrainian Congress of Soviets (December 24-25, 1917) adopted a resolution On the Donets'k-Kryvyi Rih Basin. This resolution vigorously con- 
demned the activities of the Central Council of Ukraine and of the Don's Government of the General Kaledin. The resolution claimed that they led to the split of the region and that the region's unity should have been resumed as a part of the Soviet Russia.

The $4^{\text {th }}$ regional council of the Soviets of the Donets'k-Kryvyi Rih Basin was held during February 9-12 (January 27-30) 1918. The decision was to establish a republic based on the principles of the economic sovereignty. During the short time this government adopted numerous bylaws, which allowed and promoted the nationalization of coal industry, introduced the workers' control on the factories and plants. Big houses in the cities had to be transferred to the ownership of the Soviets, workers had to form military troops on the plants. The realization started very quickly.

But Donets'k-Kryvyi Rih Republic was artificial and could not exist for a long time. The life of the Donbass state lasted for three months. On the second Council of the Soviets March 17-19, 1918 in Katerynoslav was adopted a decision Donets'k-Kryvyi Rih Republic became a part of the Soviet Ukraine (Mykhnenko, 2002).

Not only Bolshevik's goal was to control Donbas. Anton Denikin, the leader of The White movement, after gaining control over the region in the summer of 1919, tried to maximize its production capacity. Throughout the revolutionary years, the mining industry was sold part by part by owners, equipment was stolen both by workers and looters. Denikin tried with the help of loans to encourage entrepreneurs to resume production and correct the situation, but it had little results.

During autumn-winter 1919-1920 Donbass was occupied by the Bolsheviks. They started the nationalization immediately. On February 5, 1919 the Soviet Government edited the decree About the Donetsk Guberniya. According to it, it was decided to create a temporary administrative unit from Bakhmut and Slovyanoserbsk districts (povit) with the center in Luhansk. Such decision was motivated and inspired by the meaning of the region as the main coal base of the UkrSSR and for winning the civil war. In a few months industrial enterprises were nationalized and passed to Supreme Council of National Economy management (Shabelnikov, 2010). 


\section{Energy Relations after the Fall of the USSR}

Relations between independent and post-soviet Ukraine and Russia in the energy sector after the collapse of the USSR almost immediately became confrontational.

The first clash of interests took place in 1992, when the controversy surrounding the property of Ukrgazprom in the field of Urengoy. The Ukrgazprom unit developed the deposit, so all the equipment belonged to Ukraine (dozens of drilling rigs and 1,700 units of power motor vehicles). 4500 Ukrainian employees worked in the field on a permanent basis. But this did not prevent Victor Chernomyrdyn (the Prime Minister of Russian Federation in that time) from the statement (and even the threat): "We will never let the Ukrainians in Urengoy!". The threat was realized. According to the Russian Federation Presidential Decree the property of Ukrgazprom was confiscated and transferred to Gazprom (Diyak, 2009).

On February 23, 1993, the speaker of the monopoly announced Gazprom's intention to stop the gas supply to Ukraine because of the debts, which rose up to \$300 million. But the intention was left unrealized as far as Ukrainian government promised to pay the debt and in the beginning of March the first tranche was received.

Undoubtedly, in 1992-1993 already, Russian leadership began to realize the promising outlook of using "gas weapon" for achieving foreign policy goals.

However, during the 1990s, the Russian leadership did not dare to talk openly about its intentions to the of natural gas supplies and the gas price as a political factor.

But as soon as Vladimir Putin consolidated his power and world oil prices jumped up rapidly, giving additional funds for more active foreign policy, the Kremlin began to use the energy pressure factor more openly. At first, the thesis of creating an "energy superpower" was put forward. Its primary task was to establish and maintain a reliable control over oil and gas resources in Central Asia and the Transcaucasus, over routes for their transportation to European energy markets, and the long-term goal was to promote Russia's entry into European wholesale energy markets, with higher profits. The main actor in implementing this "energy strategy" was Gazprom.

For the first time, full-scale gas weapons were used in the winter of 2005-2006. The First Gas War showed the vulnerability of Ukraine and European consumers, and demonstrated how effective and promising the further use of energy weapons is.

In May 2005, the representatives of Gazprom blamed Ukraine for stealing gas, held in store for European consumers. In September they offered to buy "empty" 
gas storage facilities on the pretext that "they are still idle". The next step was the refusal to supply natural gas to Ukraine as the payment for the transit services provided at a price of $\$ 50$ per $1,000 \mathrm{~m}^{3}$. This price was established considering the principles and requirements of intergovernmental agreements.

Instead, an ultimatum was proposed a new price $-\$ 160$ for $1000 \mathrm{~m}^{3}$, and subsequently $\$ 230$. In addition, the Gazprom Chairman of the Board Oleksiy Miller immediately proclaimed that Russia, as a payment for gas supplies at a new price, is ready to acquire ownership of the Ukrainian gas transportation system instead of money. Obviously, this was precisely the goal of the Russia.

Despite the current agreements, on January 1 and 2, 2006, deliveries of Russian natural gas to Ukraine were reduced by 120 million $\mathrm{m}^{3}$ per day. On three directions (from eight) gas supply was reduced. Gas from that pipelines was for transit to European countries and Turkey, and for Ukraine as the payment for the transit services. This could have been a powerful stroke on the gas supply of the Kharkiv, Lugansk, Donetsk and Dnipropetrovsk regions, where the most energyintensive enterprises of heavy industry (chemical, metallurgical) and a significant part of the population of the country are concentrated.

Incidentally, if not massive information campaign in the mass media (no doubts, promoted and inspired by Russia), nobody in Ukraine would notice that there was a critical situation in the gas sector. This indicates that these actions were prepared in advance and deployed in accordance with the points of a definite plan. One of these points was the formation of international opinion regarding Ukraine as an unreliable partner in transporting natural gas to European countries, even though for decades Ukraine has never allowed the failures of natural gas supply to Europe through its territory. It is illustrative that at the same time as these allegations, Russia stressed the need to build the alternative to the Ukrainian system gas pipelines (North European gas pipeline in the Baltic Sea, the second gas pipeline string of the Blue Stream in the Black Sea and the expansion of the gas transmission system in Belarus, owned by Gazprom). In addition, the accusations of gas theft were not supported by concrete facts.

For example, in early May 2005, the propaganda campaign against Ukraine on "theft" of 7.8 billion $\mathrm{m}^{3}$ of gas from the underground gas storage was launched. But already on June 10, 2005 Gazprom was provided with documents that contained data on the amount of gas the underground storages. Specialists of Gazprom checked on the storages themselves, and no problems arose.

However, the Russian leadership apparently needed to discredit Ukraine as a gas transit state to European consumers. And already in July 2005, Russian President Vladimir Putin made another one statement that Ukraine "steals gas", 
citing, for example, the same artificially provoked scandal with the "theft" of Russian gas from underground storage facilities in Ukraine (Putin: Ukraina tyrit u nas $g a z, 2014)$. And that's a few weeks after Gazprom took up all the issues in official documents.

The Russia understood that in order to create an artificial energy crisis in Ukraine, in addition to terminating Russian supplies, gas supplies from Turkmenistan should be also cut off. The ability to supply gas to Ukraine from Turkmenistan directly depended on the possibility of its transit through Uzbekistan, Kazakhstan and Russia.

At the end of 2005, Gazprom gained control over transit capacities through Uzbekistan's and Kazakhstan's gas transit systems. Consequently, the opportunity to transport Turkmenistan to Turkmenistan to transport natural gas now depended directly on Russia's political will.

The Achilles' heel of the Central Asia-Central gas pipeline network is its insufficient throughput capability - only $42-44$ billion cubic meters per year. Naftogaz of Ukraine concluded an agreement for 2006 with Turkmenistan to supply 41 billion $\mathrm{m}^{3}$ of Turkmen natural gas at a price of $\$ 50$ per $1,000 \mathrm{~m}^{3}$ in the first half and $\$ 60$ in the second half of 2006. After that, Russia concluded an agreement with Turkmenistan for supply of 30 billion $\mathrm{m}^{3}$ in 2006 to Russia at a price of $\$ 65$ per $1,000 \mathrm{~m}^{3}$. Thus, considering Russian monopoly control over gas transmission lines, Ukraine was deprived of the opportunity to receive Turkmen gas. After all, such political allies of Russia as Uzbekistan in the process of natural gas transit, in essence, acted as local branches of Gazprom.

In the course of gas conflicts, Russia tried to present itself as the influential geopolitical power in order to preserve Ukraine in the sphere of its political influence. Through the blackmail and promises to keep the "special conditions" for the gas price, the Kremlin aimed to leave Ukraine in the sphere of its geopolitical influence. Moscow also tried to block the implementation of the Charter of Strategic Partnership between Ukraine and the United States regarding the modernization of the Ukrainian gas transporting system. The main policy objectives of the Moscow-Kyiv gas conflicts, inspired by the Kremlin, were to demonstrate Ukraine's transit instability and significantly impair the reputation of Ukraine as a reliable transit, geo-economic and geopolitical partner of the European Union.

The final form of the Russian strategy of using energy weapons against Ukraine became clear at the beginning of 2006. Within its boundaries, appropriate tactical targets for Ukraine were formed.

First of all, Russia invested in the construction of gas pipelines in roundabout way from Ukraine (Blue Stream, North Stream, Yamal-Europe). Secondly, 
Russia has laid full responsibility for the conflict situation in December 2005 at Ukraine's feet, and also prepared Europe for repeating the same situation.

In addition, O. Miller has officially confirmed Gazprom's intentions to switch to commercial gas prices with all consumers from the post-soviet countries. Russia's actions on transit through Ukraine and the natural gas supply to its territory under various contracts, he interpreted as a significant success for the whole Europe: "Now the conditions of supplies to Europe are not connected with the conditions of gas supplies to Ukraine" (Diyak, 2014).

This determined the forthcoming logic and strategy of Gazprom and Russian Federation concerning Ukraine. In line with this strategy were gas wars in 2006 and 2009. The significant integral part of these conflicts was informational defamation of Ukraine, disconnection from gas supply, attempts to deprive Ukraine of the trust of Western gas consumers in order to reduce the costs and gain control over the Ukrainian gas transporting system.

The use of energy weapons to achieve political strategic goals is not the knowhow of the Russian Federation. Suffice to recall the oil crisis of 1973, caused by the introduction of the OPEC embargo. Oil has never been a usual commodity, and its market was always sensitive to political fluctuations.

In the implementation of energy policy at the regional and global levels, Russia relies on natural advantages: a colossal resource base and transit potential. Energy resources is one of the most powerful weapons of the Kremlin. Energy weapon is valuable by itself. But the greatest effect is when it is combined with the appropriate use of information resources. The use of energy weapons has a future. But its effectiveness, in particular, in the Russian performance will only be reduced.

Thus, the commercial interests of Gazprom as a company once again became a victim of a political subtext, that has always been present in the Kremlin's energy diplomacy. There is even one version that the current war has been inspired, including by the leadership of Gazprom, in order to preserve Ukraine as a gas buyer (Klimovskiy, 2014). This version does not seem logical, because the war against the buyer in any case reduces its purchasing power. However, what the aggression has achieved is minimizing the chances to begin the development of shale gas in the Donbass.

Therefore, the history of Ukrainian-Russian energy relations quite logically explains their present state. Today, the energy component of the hybrid war is conventionally the second most important and powerful after the information. So, the search for answers should be no less intense, especially since Ukraine's starting points in this regard are better. 


\section{References:}

Diyak, I. (2006). Hazova viyna: shcho vidbulosya? Retrieved from: http://gasunion.org.ua/ gazova-vijna-shho-vidbulosya.htm.

Diyak, I. (2009). Hazova promyslovist' i enerhetychna bezpeka Ukrayiny. Kyyiv: Svit Uspikhu.

Gerasimov, V. (2013). Tsennost nauki v predvidenii. Retrieved from: http://vpk-news.ru/ articles/14632.

Gonchar, M., Chubyk, A., Ishchuk, O. (2015). Energy Component in New Generation Warfare. Case of Russia's Hybrid Aggression Against Ukraine. Retrieved from: https://geostrategy.org.ua/images/August_2015_Hybrid_Aggression_final.pdf.

Hoffman, F. (2014). On Not-So-New Warfare: Political Warfare vs. Hybrid Threats. Retrieved from: http://warontherocks.com/2014/07/on-not-so-new-warfare-politicalwarfare-vs-hybrid-threats/.

Klimovskiy, S. (2014). Voyna pod znamenem Gazproma. Retrieved from: http://hvylya. net/analytics/politics/voyna-pod-znamenem-gazproma.html.

Mattis, J.N., Hoffman, F. (2005). Future Warfare: The Rise of Hybrid Wars. Retrieved from: http://milnewstbay.pbworks.com/f/MattisFourBlockWarUSNINov2005.pdf.

Mustonen, T. (2014). The Weekly Recap: Hybrid War - The Ukrainian Example. Retrieved from: http://defencereport.com/defrep-analysis-hybrid-war-the-ukrainian-example/.

Mykhnenko, A. (2002). Istoriya Donets'koho baseynu druhoyi polovyny KhIKh - pershoyi polovyny KhKh st. Dnipropetrovs'k: Dnipropetrovs'kyy natsional'nyy un- t.

Gregory, P. (2014). Putin Is Winning: EU Backs Away From Ukraine Trade Pact; U.S. On The Sidelines. Retrieved from: http://www.forbes.com/sites/paulroderickgregory/2014/10/02/as-russia-intimidates-europe-obama-fiddles-on-energy-policy/.

Putin: Ukraina tyrit u nas gaz. (2005). Retrieved from: http://fraza.ua/news/09.07.05/4391. html.

Shabel'nikov, V. (2010). Pro vydilennya Donbasu v yedynyy administratyvno-terytorial'nyy i ekonomichnyy rehion Ukrayiny (1919-1921 pp.). In: Novi storinky istoriyi Donbasu, 164-170 Donets'k, DonNU.

Yefimenko, H. (2008). Vzayemovidnosyny Kremlya ta radians'koyi Ukrayiny: ekonomichnyy aspekt (1917-1919 rr.). Kyiv: Instytut istoriyi Ukrayiny. 